Supporting Information For:

\title{
Influence of the Heating Rate on the Quality of Metallurgical Coke
}

\author{
María F. Vega*, Elvira Díaz-Faes, Carmen Barriocanal \\ Instituto de Ciencia y Tecnología del Carbono, INCAR-CSIC \\ Francisco Pintado Fe 26, 33011 Oviedo, Spain \\ Corresponding autor:m.vega@incar.csic.es
}



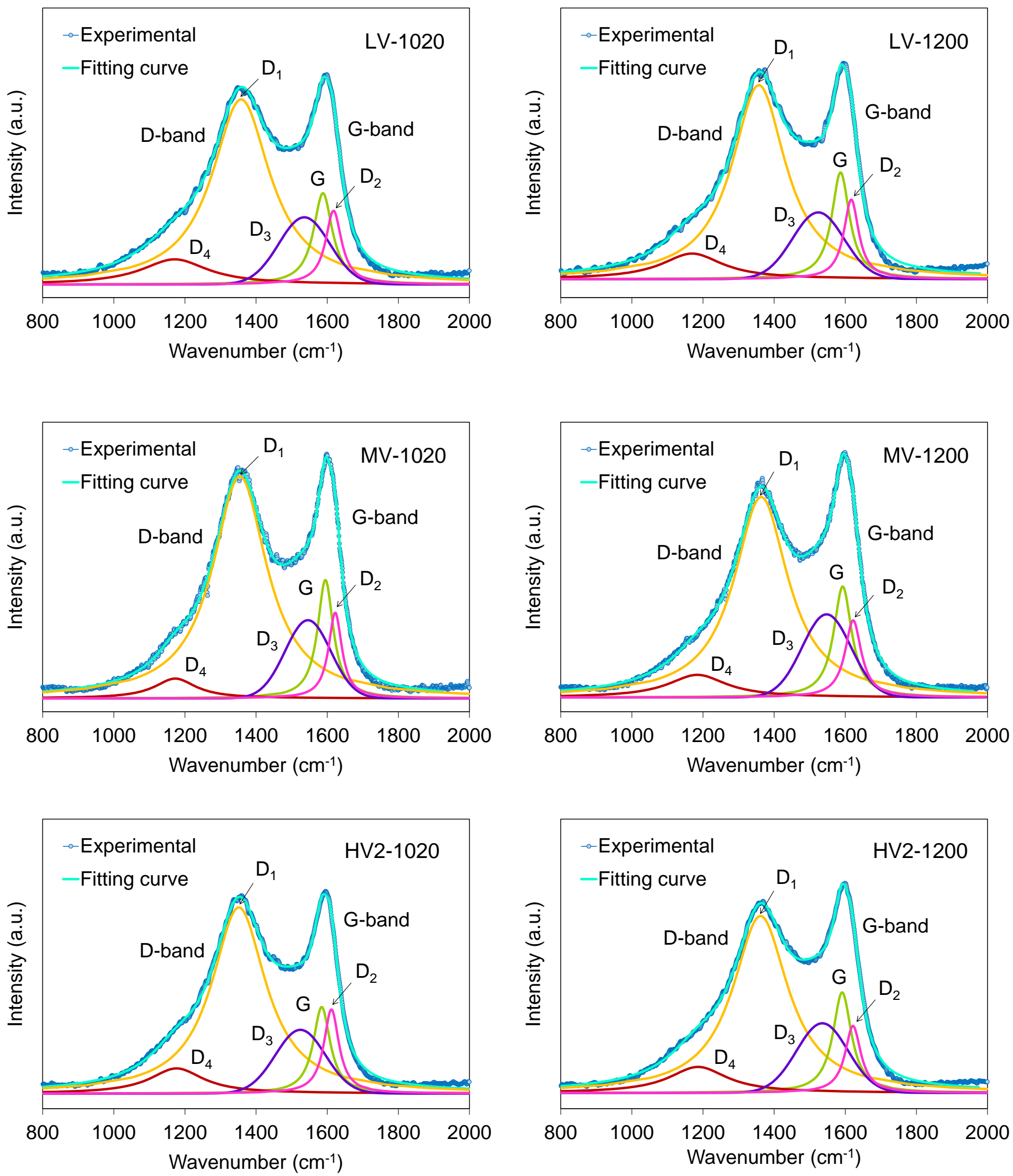

Figure S1. Curve fit Raman spectra of cokes obtained from LV, MV and HV2 coals at different temperature. 